\title{
Analisis Kuantitatif Kadar Nitrit dalam Produk Daging Olahan di Wilayah Denpasar Dengan Metode Griess Secara Spektrofotometri
}

\author{
Nur Habibah ${ }^{1 *}$, I G.A. Sri Dhyanaputri ${ }^{2}$, I Wayan Karta ${ }^{3}$, Ni Nyoman Astika Dewi ${ }^{4}$
}

1,2,3,4 Jurusan Analis Kesehatan Politeknik Kesehatan Kemenkes Denpasar, Bali

\author{
A R T I C L E I N F O \\ Article history: \\ Received 19 November \\ 2017 \\ Received in revised form \\ 10 Desember 2017 \\ Accepted 12 Januari 2018 \\ Available online 25 \\ Februari 2018

\section{Kata Kunci:} \\ metode Griess, analisis nitrit \\ dalam produk daging \\ olahan, metode \\ spektrofotometri \\ Keywords: \\ Griess method, nitrite \\ analysis in the meat \\ product, spectrophotometric
}

\begin{abstract}
A B S T R A K
Nitrit merupakan salah satu jenis bahan tambahan pangan (BTP) yang penting, terutama dalam pengolahan produk daging olahan. Nitrit banyak digunakan sebagai pengawet pada berbagai jenis daging olahan seperti sosis, kornet, nugget dan lain-lain. Berbagai dampak negatif nitrit terhadap kesehatan manusia telah banyak dilaporkan. Kelebihan nitrit dalam darah mampu menyebabkan terjadinya defisiensi oksigen akibat pembentukan methemoglobin sehingga menyebabkan sindrom blue-baby pada bayi. Untuk menjamin kemanan bahan pangan, pemerintah telah mengatur ambang batas maksimal kandungan nitrit sebagai pengawet dalam produk daging olahan melalui Permenkes nomor 1168/Menkes/Per/X/1999 yaitu sebesar $125 \mathrm{mg} / \mathrm{kg}$ bahan. Analisis dan monitoring kontinyu kandungan pengawet nitrit dalam bahan pangan sangat penting dilakukan. Sampel yang digunakan dalam penelitian ini adalah 18 sosis berbeda merk yang diperoleh dari berbagai wilayah di Denpasar. Pada penelitian ini analis kuantitatif nitrit dalam sampel sosis dilakukan dengan metode Griess secara spektrofotometri. Absorbansi larutan standar dan sampel diukur pada panjang gelombang $520 \mathrm{~nm}$ setelah diinkubasi selama 30 menit. Hubungan yang linier diperoleh dengan pengukuran larutan standar pada rentang konsentrasi 0,1-0,5 ppm dengan harga $\mathrm{R} 2$ sebesar 0,997. Berdasarkan hasil pengukuran absorbansi sampel dan persamaan regresi linier yang telah diperoleh, diketahui bahwa terdapat 6 sampel uji sosis memiliki kandungan nitrit diatas ambang batas yang telah ditetapkan, yaitu lebih dari $125 \mathrm{mg} / \mathrm{kg}$ bahan.
\end{abstract}

\section{A B S T R A C T}

Nitrite is one of important food additive that used as a preservative and curing agent for the meat product. Since the adverse effect of nitrites to the human health has been reported, the government regulated maximum allowable nitrite content in meat product is $125 \mathrm{mg} / \mathrm{kg}$. Hence, continuous monitoring of the existence of nitrite, especially in the meat products are important to conducted. Quantitative analysis of nitrite in the meat product, especially sausage has been described. The spectrophotometric measurement of the nitrite contents was conducted by using Griess method. The absorbance of both standard solution and sample carried after 30 minutes at the maximum wavelength $520 \mathrm{~nm}$. A linier calibration curve was obtained in the range of 0.1-0.5 ppm, with the $R^{2}$ value is 0.997 . Subsequently, the method was applied to determine the nitrit contents in sausage samples. The spectrophotometric determination showed there were 6 samples have nitrite contents more than maximum allowable nitrite content in the meat product.

\footnotetext{
* Corresponding author.

E-mail addresses: nur.habibah.poltekkesdps@gmail.com ( Nur Habibah)
} 


\section{Pendahuluan}

Dewasa ini, perubahan gaya hidup masyarakat modern menjadi hal yang menyita perhatian banyak pihak. Kesibukan masyarakat modern yang semakin meningkat mengakibatkan waktu luang yang tersisa semakin sempit, sehingga masyarakat cenderung memilih hal yang mudah dan praktis, tidak terkecuali dalam hal memilih makanan. Makanan cepat saji menjadi pilihan sebagian masyarakat dan dinilai lebih menguntungkan karena lebih mudah dalam proses pengolahan serta memiliki harga yang terjangkau dengan rasa yang lezat. Fenomena peningkatan konsumsi makanan cepat saji menunjukkan tren peningkatan pada hampir semua kelompok usia. Hal ini tentu saja membawa dampak terhadap berbagai aspek kehidupan, terutama aspek kesehatan. Beberapa hasil penelitian menunjukkan bahwa konsumsi makanan cepat saji tersebut dapat meningkatkan peluang terjadinya masalah gizi, obesitas bahkan terjadinya penyakit degenerative (Mardatillah, 2008).

Salah satu jenis makanan cepat saji yang banyak dikonsumsi oleh sebagian masyarakat adalah produk daging olahan. Salah satu jenis daging olahan yang banyak dikonsumsi adalah sosis. Sosis merupakan salah satu produk daging olahan yang mempunyai nilai gizi yang tinggi. Namun, komposisi gizi dalam sosis berbeda-beda, tergantung pada jenis daging yang digunakan dan proses pengolahannya. Saat ini sosis menjadi jajanan yang tidak hanya digemari oleh anak-anak namun juga digemari oleh orang dewasa bahkan orang tua. Jenis daging olahan yang satu ini dapat ditemukan dengan mudah di pasar, di warung hingga di sekolah-sekolah.

Daging merupakan salah satu sumber protein hewani yang banyak dibutuhkan oleh tubuh. Selain mengandung protein, daging juga mengandung komponen lain seperti mineral, lemak, dan karbohidrat. Daging merupakan bahan pangan yang mudah rusak karena aktivitas mikroorganisme seperti fungi dan bakteri, sehingga dalam proses pengolahannya sering kali ditambahkan bahan tambahan pangan (BTP), khususnya pengawet (Saparinto and Diana, 2006). Secara umum, BTP ditambahkan ke dalam produk pangan dengan tujuan untuk mempengaruhi sifat atau bentuk pangan. Terdapat berbagai jenis BTP, salah satunya adalah pengawet. Penggunaan bahan pengawet dilakukan dengan tujuan untuk mencegah atau menghambat proses fermentasi, pengasaman, penguraian dan perusakan lainnya terhadap bahan pangan yang disebabkan oleh mikroorganisme sehingga mampu memperpanjang umur simpan makanan (Menkes R.I., 2012). Penambahan BTP ke dalam bahan pangan harus diperhatikan agar kadarnya tidak melebihi batas toleransi tubuh.

Pengawet yang sering ditambahkan ke dalam produk daging olahan adalah garam nitrit. Selain digunakan sebagai pengawet, nitrit juga ditambahkan ke dalam daging olahan dalam proses curing untuk memberikan warna merah khas daging. Diketahui bahwa nitrit bersama dengan natrium klorida mampu menghambat produksi neurotoksin yang dihasilkan oleh bakteri Clostridium botulinum sehingga mampu mencegah keracunan dan pembusukan. Hal ini tentu saja dapat meningkatkan umur simpan daging olahan. Akan tetapi, penggunaan nitrit juga dapat memberikan dampak negatif karena nitrit diketahui dapat memicu pembentukan senyawa nitrosamin yang bersifat teratogenik, mutagenik bahkan karsinogenik, melalui reaksi dengan amina sekunder atau tersier yang ada di dalam tubuh (Gómez et al., 2015; Pourezza et al., 2012; Zatar et al., 1999). Selain itu, konsentrasi nitrit yang berlebih juga diketahui sangat berbahaya, tertama bagi ibu hamil dan bayi. Tingginya konsentrasi nitrit dalam darah dapat menyebabkan nitrit bereaksi dengan hemoglobin membentuk methemoglobin, dengan cara mengoksidasi Fe(II) pada hemoglobin menjadi Fe(III). Kondisi ini disebut methemoglobinemia. Kondisi ini sangat berbahaya, terutama pada bayi. Tidak seperti hemoglobin, methemoglobin diketahui tidak memiliki kemampuan untuk mengangkut oksigen. Hal ini menyebabkan terjadinya defisiensi oksigen sehingga menyebabkan kulit bayi menjadi biru. Kondisi methemoglobinemia pada bayi ini sering disebut dengan sindrom blue-baby (Gürkan and Altunay, 2015; Nagaraja et al., 2010).

Metode yang paling banyak digunakan untuk menentukan kadar nitrit dalam suatu sampel adalah spektrofotometri. Metode spektrofotometri menawarkan kelebihan dibandingkan dengan metode yang lain seperti fluorometri, elektrokimia, polarografi, amperometri, kromatografi dan potensiometri, karena lebih sederhana, murah, mudah serta memiliki akurasi, presisi dan limit deteksi yang sangat baik (Pourezza et al., 2012; Gürkan and Altunay, 2015). Analisis kadar nitrit secara spektrofotometri dilakukan dengan metode Griess. Pada metode Griess, analisis kadar nitrit dilakukan berdasarkan pada reaksi diazotasi dari suatu amina aromatik dengan nitrit dalam suasana asam, yang diikuti dengan reaksi kopling sehingga menghasilkan senyawa azo yang berwarna merah-ungu. Selanjutnya, senyawa azo yang terbentuk diukur absorbansinya pada rentang panjang gelombang 500-600, sehingga kadar nitrit dapat ditentukan (Pourezza et al., 2012; Moorcroft et al., 2001; Gandjar and Rohman, 2007).

Penentuan kadar nitrit dalam produk daging olahan, salah satunya sosis, merupakan hal yang sangat penting dilakukan untuk monitoring kemananan bahan pangan. Pemerintah Republik Indonesia melalui Peraturan Menteri Kesehatan Nomor 168/Menkes/Per/X/1999 telah mengatur bahwa 
penambahan nitrit sebagai pengawet ke dalam produk daging olahan tidak boleh melebihi $125 \mathrm{mg} / \mathrm{kg}$. Sejauh ini, informasi mengenai kadar atau jumlah nitrit yang ditambahkan sebagai pengawet ke dalam produk daging olahan belum dapat ditemukan dengan jelas pada kemasan bahan. Oleh karena itu, pada penelitian ini dilakukan analisis kuantitatif nitrit secara spektrofotometri dalam berbagai merk sosis. Analisis nitrit dilakukan dengan metode Griess secara spektrofotometri dengan menggunakan senyawa amina asam sulfanilamida dengan agen pengkopling N-1-naftiletilen-diamonium dihidroklorida (NEDA).

\section{Metode}

Penelitian ini merupakan jenis penelitian deskriptif observasional. Penelitian dilakukan dengan menganalisis kadar nitrit secara kuantitatif dalam berbagai 18 merk sosis yang diperoleh dari berbagai toko di wilayah Denpasar. Penelitian ini dilakukan di Laboratorium Kimia dasar dan Kimia Terapan Jurusan Analis Kesehatan pada bulan Mei 2017. Analisis nitrit dilakukan dengan Metode Griess, dengan pengukuran secara spektrofotometri

\section{Hasil dan pembahasan}

\section{Pembuatan kurva standar natrium nitrit}

Berdasarkan hasil pengukuran absorbansi terhadap satu seri larutan standar natrium nitrit, diperoleh data sebagai berikut:

Tabel 1. Data Absorbansi Larutan Standar Natrium Nitrit

\begin{tabular}{ccc}
\hline No. & Konsentrasi (ppm) & Absorbansi \\
\hline 1. & 0 & 0 \\
2. & 0,1 & 0,074 \\
3. & 0,2 & 0,133 \\
4. & 0,3 & 0,183 \\
5. & 0,4 & 0,247 \\
6. & 0,5 & 0,304 \\
\hline
\end{tabular}

Selanjutnya berdasarkan hasil pengukuran absorbansi larutan standar yang disajikan pada Tabel 1 tersebut, dibuat kurva standar untuk menentukan persamaan regresi linier dan harga $\mathrm{R}^{2}$.

Pengukuran absorbansi sampel sosis

Berdasarkan hasil pengukuran absorbansi terhadap 18 sampel sosis berbeda merk, diperoleh data sebagai berikut:

Tabel 2. Data Absorbansi Sampel Sosis.

\begin{tabular}{cccc}
\hline No. & Kode Sampel & Rata-Rata Absorbansi & Kadar nitrit (ppm) \\
\hline 1 & 2 & 3 & 4 \\
\hline 1. & A1 & 0,073 & 0,274 \\
2. & B1 & 0,184 & 0,740 \\
3. & C1 & 0,211 & 0,852 \\
4. & D1 & 0,105 & 0,408 \\
5. & E1 & 0,222 & 0,898 \\
6. & F1 & 0,560 & 2,314 \\
7. & G1 & 0,235 & 0,952 \\
8. & H1 & 0,086 & 0,328 \\
9. & I1 & 0,086 & 0,328 \\
10. & I & 0,352 & 1,442 \\
11. & K1 & 0,209 & 0,844 \\
12. & L1 & 0,121 & 0,475 \\
13. & M1 & 0,541 & 2,234 \\
14. & N1 & 0,496 & 2,046 \\
15. & O1 & 0,494 & 2,037 \\
16. & P1 & 0,132 & 0,520 \\
17. & 1 & 0,139 & 0,550 \\
18. & R1 & 0,430 & 1,769 \\
\hline
\end{tabular}


*Kadar nitrit (ppm) setelah memperhitungkan faktor pengenceran

Kadar nitrit dalam sampel sosis ditentukan dengan cara memasukkan data absorbansi sampel yang disajikan pada Tabel 2 ke dalam persamaan regresi linier kurva standar yang telah ditentukan sebelumnya. Berdasarkan hasil pengukuran absorbansi dan pengamatan visual sampel setelah ditambahkan pereaksi, terdapat hubungan yang sebanding antara warna sampel dengan absorbansi yang terukur. Semakin pekat warna ungu yang dihasilkan oleh sampel, maka absorbansi yang terukur juga semakin tinggi.

\section{Penentuan kadar nitrit dalam sampel sosis $(\mathrm{mg} / \mathrm{kg})$}

Berdasarkan hasil pengukuran absorbansi dan perhitungan, diperoleh hasil analisis kadar nitrit dalam sampel sosis $(\mathrm{mg} / \mathrm{kg})$ dengan data sebagai berikut:

Tabel 3. Kadar Nitrit dalam Sampel Sosis

\begin{tabular}{cccc}
\hline No. & Kode Sampel & Kadar Nitrit $(\mathrm{mg} / \mathrm{kg})$ & Kriteria \\
\hline 1 & 2 & 3 & 4 \\
\hline 1. & A1 & 27,392 & MS \\
2. & B1 & 74,007 & MS \\
3. & C1 & 85,190 & MS \\
4. & D1 & 40,794 & MS \\
5. & E1 & 89,797 & MS \\
6. & F1 & 231,362 & TMS \\
7. & G1 & 95,242 & MS \\
8. & H1 & 32,836 & MS \\
9. & I1 & 32,836 & MS \\
10. & J1 & 144,245 & TMS \\
11. & K1 & 84,352 & MS \\
12. & L1 & 47,495 & TMS \\
13. & M1 & 223,404 & TMS \\
14. & N1 & 204,557 & TMS \\
15. & O1 & 203,719 & MS \\
16. & P1 & 51,977 & MS \\
17. & Q1 & 55,034 & TMS \\
18. & R1 & 176,914 & \\
\hline
\end{tabular}

Keterangan:

MS : Memenuhi syarat, yaitu kurang dari $125 \mathrm{mg} / \mathrm{kg}$

TMS : Tidak memenuhi syarat, yaitu lebih dari $125 \mathrm{mg} / \mathrm{kg}$

Berdasarkan data yang disajikan pada Tabel 3, dapat diketahui bahwa terdapat nitrit dengan kadar yang bervariasi pada sampel sosis yang telah dianalisis. Diketahui bahwa terdapat 6 sampel sosis memiliki kadar nitrit melebihi baku mutu yang telah ditentukan menurut Peraturan Menteri Kesehatan nomor 1168/Menkes/Per/X/1999. Keenam sampel sosis tersebut adalah sampel F1, J1, M1, N1, 01 dan R1 dengan kadar nitrit berturut-turut adalah sebesar 231,362; 144,245; 223,404; 204,557; 203,719; dan $176,914 \mathrm{mg} / \mathrm{kg}$. Kandungan nitrit terendah ditemukan pada sampel A1 dengan kadar sebesar 27,392 $\mathrm{mg} / \mathrm{kg}$.

\section{Analisis kadar nitrit dengan metode Griess secara spektrofotometri menggunakan asam sulfanilamida dan NEDA}

Analisis nitrit pada penelitian ini dilakukan dengan metode Griess secara spektrofotometri. Ion nitrit yang terkandung dalam sampel direaksikan dengan senyawa amina primer pada suasana asam sehingga menghasilkan ion benzenadiazonium. Selanjutnya, ion benzenadiazodium dikoplingkan dengan turunan senyawa benzena, naftalena atau senyawa heterosiklik yang lain sehingga akan menghasilkan senyawa azo yang berwarna merah ungu (Moorcroft et al., 2001; Sun, et al., 2003). Pengukuran absorbansi senyawa azo ini dapat dilakukan pada rentang panjang gelombang 500-600 nm (Moorcroft et al., 2001). Secara umum mekanisme reaksi Griess dapat dilihat pada Gambar 1. 


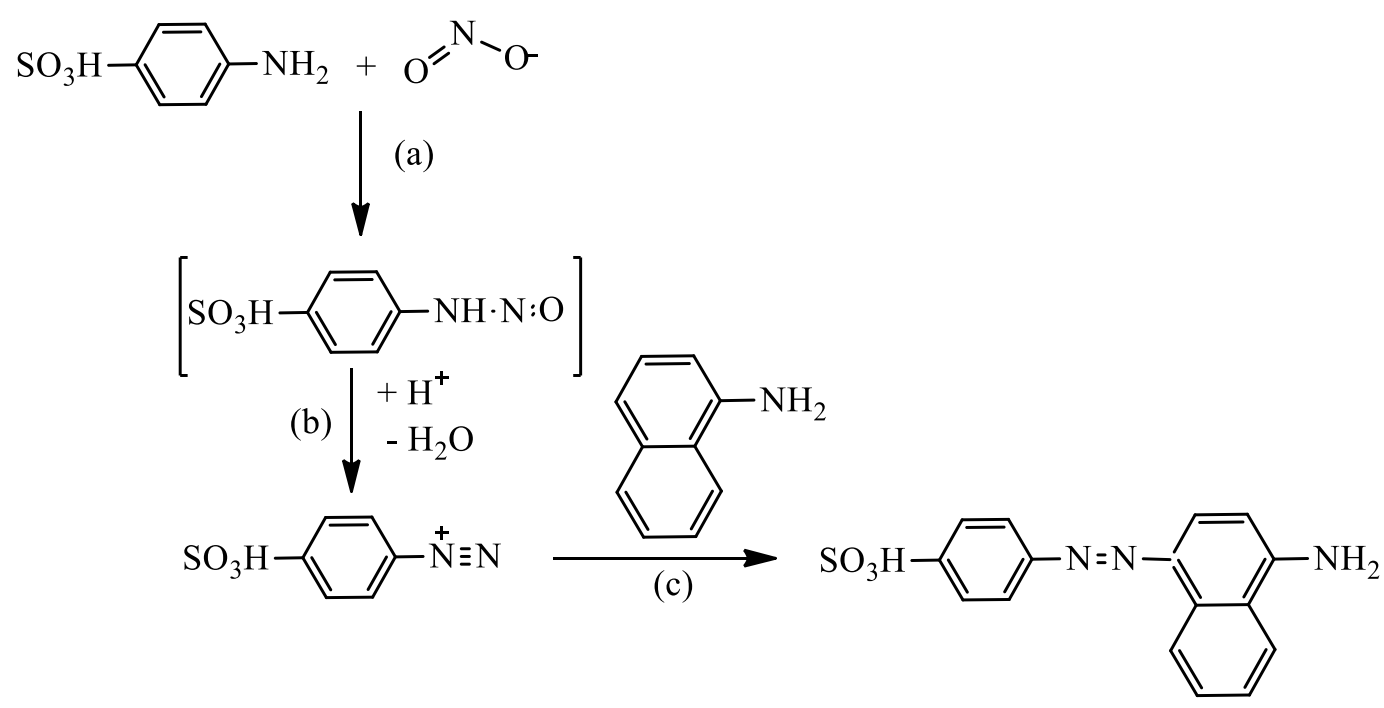

Senyawa azo

Gambar 1. Reaksi Griess antara sulfanilik pada kondisi asam yang dikopling dengan $\alpha$ - naftilamina

Meskipun agen pengkopling dan senyawa amina primer lain telah banyak dikembangkan, namun metode standar penentuan nitrit dengan metode Griess masih menggunakan asam sulfanilamida sebagai senyawa amina dan NEDA sebagai agen pengkopling. Pada penelitian ini, ion nitrit yang terkandung dalam sampel direaksikan dengan asam sulfanilamida dalam suasana asam. Selanjutnya ion benzenadiazonium yang terbentuk akan dikopling dengan N-1-naftiletilen-diamonium dihidroklorida (NEDA) sehingga menghasilkan senyawa azo yangberwarna ungu. Selanjutnya senyawa azo yang terbentuk diukur absorbansinya pada panjang gelombang maksimum yang diperoleh dalam penelitian ini, yaitu $520 \mathrm{~nm}$. Struktur senyawa azo yang terbentuk dari hasil reaksi nitrit dengan asam sulfanilamida dan NEDA disajikan pada Gambar 2 (Sun et al., 2003).

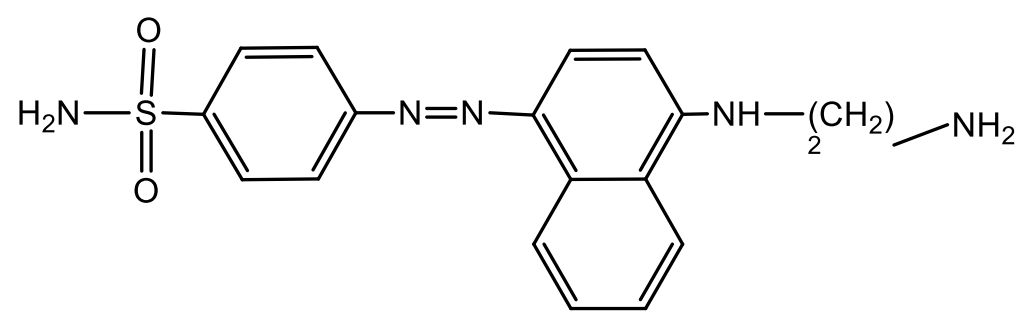

Gambar 2. Struktur senyawa azo yang terbentuk dari hasil reaksi antara nitrit dengan asam sulfanilamida dan NEDA

Pada analisis nitrit dengan metode Griess, terdapat beberapa hal yang perlu diperhatikan, antara lain adalah $\mathrm{pH}$, temperatur dan waktu pengkoplingan. Hal ini disebabkan karena pembentukan senyawa azo sangat tergantung pada kondisi $\mathrm{pH}$, temperatur reaksi diazotasi serta waktu pengkoplingan. Beberapa literatur menyebutkan bahwa waktu optimum yang diperlukan untuk pembentukan senyawa azo hingga terbentuk sempurna adalah sekitar 40 menit (Aydin et al., 2005). Penelitian yang lain menyebutkan bahwa pembentukan senyawa azo memerlukan waktu selama 30 menit, selanjutnya senyawa azo yang terbentuk akan stabil setelah menit ke-30 (Gürkan and Altunay, 2015; Sun et al., 2003). Berdasarkan beberapa hasil penelitian tersebut, maka pada penelitian ini pengukuran absorbansi larutan standar dan sampel dilakukan 30 menit setelah penambahan agen pengkopling pada larutan campuran. Selanjutnya pengukuran absorbansi larutan standar dan sampel dilakukan pada panjang gelombang maksimum yang diperoleh, yaitu $520 \mathrm{~nm}$.

\section{Pembuatan kurva standar natrium nitrit}

Pengukuran konsentrasi sampel pada penelitian ini dilakukan dengan metode kurva kalibrasi. Metode kurva kalibrasi memiliki kelebihan karena menggunakan lebih daru satu konsnetrasi larutan standar, sehingga hasil pengukurannya lebih akurat. Pada penelitian ini, kurva kalibrasi dibuat dengan 
menggunakan 5 konsentrasi larutan standar yang berbeda, yaitu 0,$1 ; 0,2 ; 0,3 ; 0,4$ dan 0,5 ppm. Berdasarkan hasil pengukuran absorbansi larutan standar yang disajikan pada Tabel 2, diperoleh kurva kalibrasi yang disajikan pada Gambar 3.

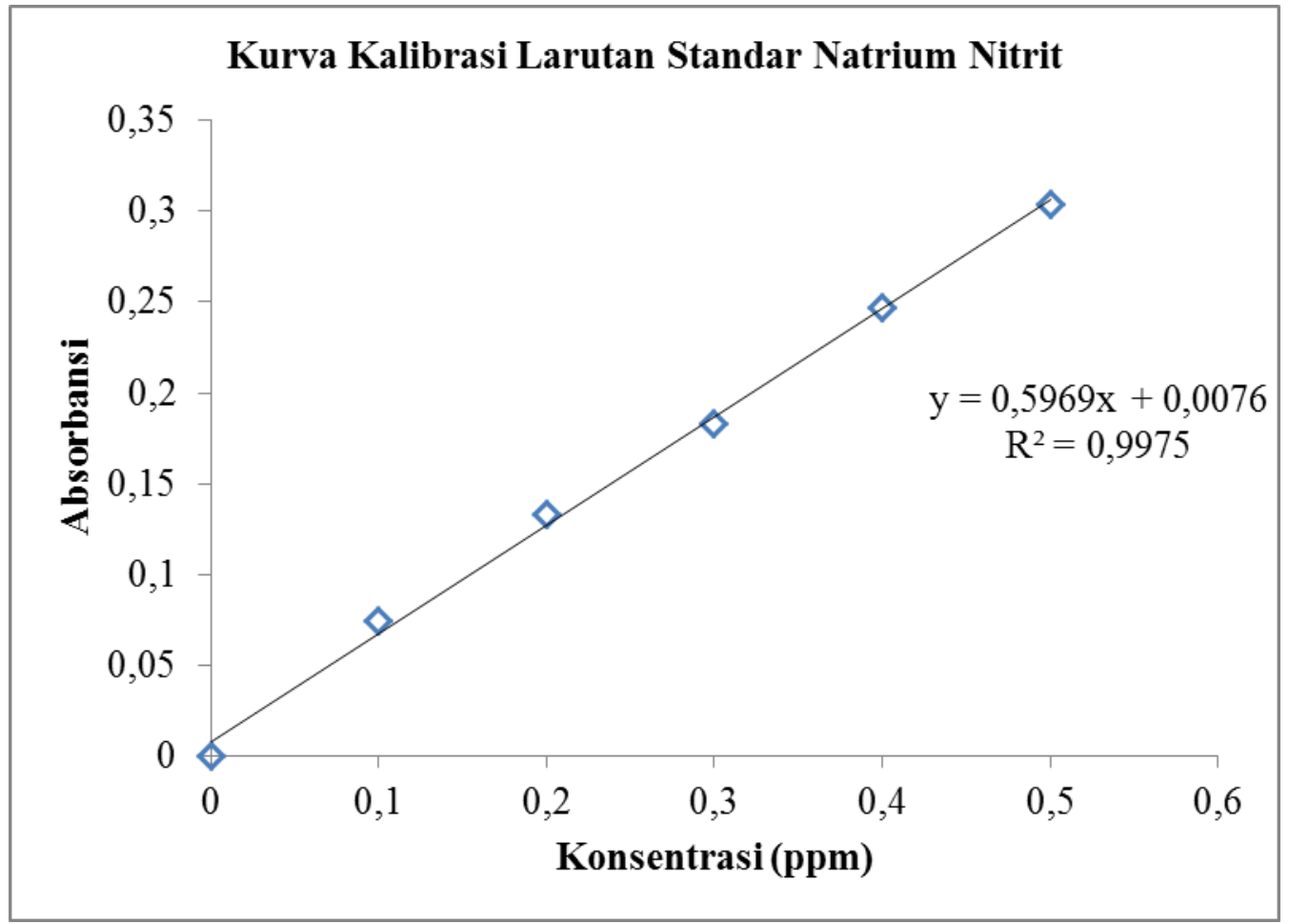

Gambar 3. Kurva kalibrasi larutan standar natrium nitrit

Kurva kalibrasi larutan standar natrium nitrit yang disajikan pada Gambar 3 menunjukkan bahwa terdapat hubungan yang linier antara konsentrasi dan absorbansi larutan standar nitrit pada rentang konsentrasi 0,1-0,5 ppm dengan harga $\mathrm{R}^{2}$ sebesar 0,9975. Persamaan regresi linier yang diperoleh adalah $y=0,5969 x+0,0076$. Linieritas yang diperoleh pada penelitian ini telah memenuhi batas linieritas yang disyaratkan, yaitu $\geq 0,995$. Selanjutnya, kurva kalibrasi ini digunakan untuk menentukan konsentrasi nitrit dalam sampel dengan cara memasukkan absorbansi sampel yang terukur ke dalam persamaan regresi linier dari kurva kalibrasi yang diperoleh.

Penentuan kadar nitrit dalam sampel sosis berdasarkan hasil pengukuran absorbansi

Jumlah sampel yang dianalisis dalam penelitian ini adalah sebanyak 18 sampel sosis berbeda merk yang diperoleh secara acak dari berbagai toko di wilayah Denpasar. Selanjutnya sampel dipreparasi dan ditentukan kadar nitritnya secara spektrofotometri. Penentuan kadar nitrit dalam sampel dilakukan berdasarkan rata-rata hasil pengukuran absorbansi yang terukur.

Berdasarkan data absorbansi sampel yang disajikan pada Tabel 2, dapat diketahui bahwa semua sampel sosis mengandung nitrit dengan kadar yang bervariasi. Berdasarkan data tersebut, dapat diketahui bahwa kandungan nitrit terkecil ditemukan dalam sampel A1 dengan kadar sebesar 27,392 $\mathrm{mg} / \mathrm{kg}$ dan terbesar pada sampel F1 dengan kadar sebesar 231,362 mg/kg. Berdasarkan hasil pengkuran dan perhitungan, diketahui bahwa terdapat 6 sampel sosis yang memiliki kadar nitrit melebihi baku mutu yang telah ditetapkan oleh Permenkes nomor 1168/Menkes/Per/X/1999, yaitu sebesar $125 \mathrm{mg} / \mathrm{kg}$. Sampel sosis tersebut adalah sampel F1, J1, M1, N1, 01 dan R1 dengan kadar nitrit berturut-turut adalah sebesar 231,362; 144,245; 223,404; 204,557; 203,719 dan 176,914 mg/kg. Sebaran kadar nitrit dalam sampel sosis disajikan pada Gambar 4.

Beberapa hasil penelitian lain menunjukkan hasil yang sejalan dengan penelitian yang telah dilakukan. Berdasarkan hasil pengukuran diketahui bahwa kadar nitrit pada berbagai produk daging olahan di beberapa daerah di Indonesia menunjukkan hasil yang bervariasi. Beberapa produk daging olahan mengandung kadar nitrit dibawah baku mutu yang telah diatur, sehingga aman untuk dikonsumsi, tetapi tidak sedikit juga produk yang memiliki kadar nitrit diatas baku mutu yang telah ditentukan (Cory, 2009; Purbanugraha, 1998; Husni et al., 2007; Nur and Suryani, 2012; Siregar, 2003). 


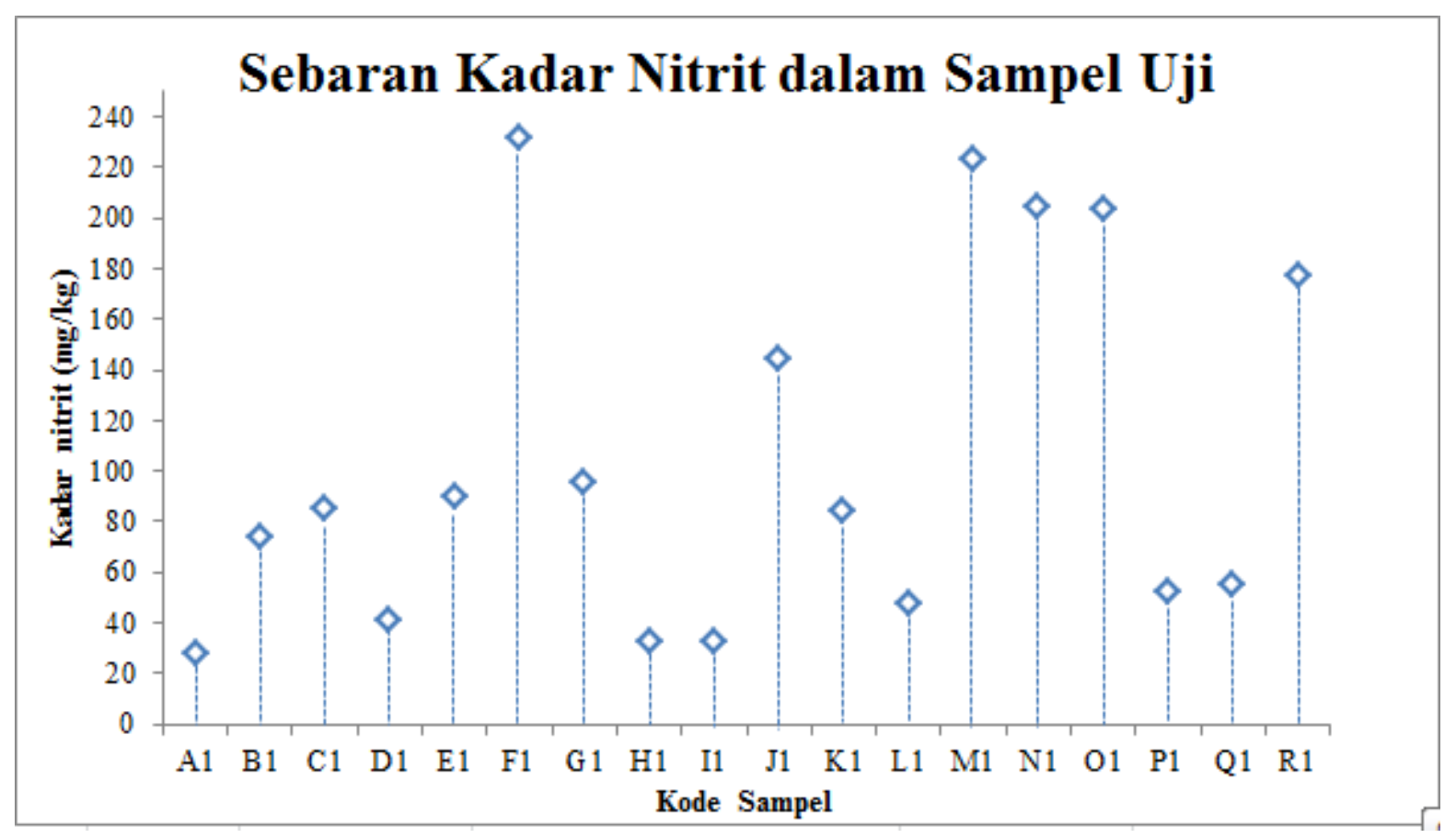

Gambar 4. Sebaran Kadar Nitrit dalam Sampel Uji

Berdasarkan hasil pengukuran, diketahui bahwa terdapat beberapa sampel sosis memiliki kadar nitrit diatas baku mutu yang telah dipersyaratkan, yaitu melebihi $125 \mathrm{mg} / \mathrm{kg}$. Hal ini tentu saja perlu mendapatkan perhatian khusus dari instansi terkait seperti BPOM atau Depkes setempat. Monitoring berkala sangat perlu dilakukan untuk memastikan keamanan bahan pangan yang beredar di masyarakat, apalagi sekarang ini sosis telah menjadi jajanan yang sangat disukai anak-anak dan dapat ditemukan dengan sangat mudah dengan harga yang terjangkau. Informasi komposisi pada kemasan bahan pangan juga harus menjadi perhatian, karena sejauh ini, komposisi terutama jumlah atau kadar BTP yang ditambahkan ke dalam bahan pangan belum dapat ditemukan secara jelas. Regulasi tentang Label dan Periklanan Makanan, sebagaimana tertuang dalam Peraturan Menteri Kesehatan R.I. No. 79/Menkes/Per/III/1978 seyogyanya dapat disosialisasikan dengan jelas, supaya dapat dipatuhi dengan baik oleh produsen dan dipahami dengan baik pula oleh konsumen.

Dalam produk daging olahan, natrium nitrit bersama dengan natrium nitrat sering ditambahkan sebagai bahan pengawet. Nitrit bersama dengan natrium klorida diketahui mampu menghambat pertumbuhan bakteri Clostridium botulinum sehingga dapat memperpanjang masa simpan produk (Gómez et al., 2015). Natrium nitrit juga sering digunakan dalam proses curing daging untuk memperoleh warna merah pink alami daging sehingga lebih menarik konsumen. Sampai saat ini, nitrit masih menjadi pilihan utama pada proses pengawetan dan curing daging karena dapat menghasilkan hasil yang cukup baik. Salah satu cara yang dapat ditempuh untuk mengurangi resiko penyakit karena penggunaan nitrit sebagai pengawet secara berlebih adalah dengan cara mengurangi jumlah nitrit yang ditambahkan kedalam produk daging olahan. Hal ini dapat dilakukan dengan mengkombinasikan nitrit dengan bahan anti-mikroba lain seperti sorbat, vitamin $\mathrm{C}$ atau $\mathrm{E}$ ke dalam produk daging daging olahan untuk menghambat reaksi nitrosasi sekaligus memperpanjang masa simpan bahan (Muctadi, 1989).

Konsumsi sosis atau jenis daging olahan lain yang memiliki kadar nitrit berlebih tentu berbahaya bagi kesehatan. Kelebihan konsentrasi nitrit dalam tubuh dapat menyebabkan toksisitas akut maupun kronik. Berdasarkan informasi data yang diperoleh dalam MSDS, natrium nitrit memiliki efek toksisitas akut pada pada hewan uji, yaitu tikus dan mencit melalui rute oral dengan harga $\mathrm{LD}_{50}$ berturut-turut adalah sebesar 180 dan $175 \mathrm{mg} / \mathrm{kg}$. Selain itu nitrit juga berpotensi menyebabkan toksisitas kronik karena dilaporkan bersifat mutagenik baik pada sel somatik mamalia dan bakteri atau jamur, serta bersifat teratogenik pada manusia (Science Lab., tt). Toksisitas kronik ini kemungkinan terjadi karena kelebihan konsentrasi nitrit dalam tubuh dapat menyebabkan nitrit bereaksi dengan amina sekunder atau tersier di dalam tubuh sehingga dapat memicu pembentukan senyawa nitrosamin yang bersifat teratogenik hingga karsinogenik (Pourezza, 2012; Nagaraja, 2010; Aydin et al., 2005). Potensi toksisitas kronik ini dapat meningkat karena nitrit juga dilaporkan bersifat kumulatif dalam tubuh manusia.

Paparan nitrit dengan konsentrasi yang sangat tinggi juga dapat menyebabkan terjadinya toksisitas akut. Dalam konsentrasi yang berlebih dalam darah, nitrit dapat bereaksi dengan Fe(II) pada hemoglobin 
membentuk methemoglobin yang tidak memiliki kemampuan untuk mengangkut oksigen. Akibatnya, terjadi defisiensi oksigen di dalam tubuh. Penyakit ini dapat berakibat fatal, terutama jika terjadi pada bayi dan ibu hamil. Defisiensi oksigen akibat methemoglobinemia akan menyebabkan kulit menjad pucat, sianosis (kulit berubah warna menjadi kebiru-biruan), sesak nafas, muntah hingga shock. Bahkan, methemoglobinemia dapat menyebabkan kematian jika kadar methemoglobinemia dalam darah melebihi 70\% (Zatar et al., 1999; Nur and Suryani, 2012). Untuk menjamin keamanan bahan pangan, pemerintah R.I. telah mengatur batas maksimal BTP nitrit dalam produk daging olahan yaitu sebesar $125 \mathrm{mg} / \mathrm{kg}$. Sedangkan Acceptable Daily Intake nitrit telah dibatasi hingga $0,06 \mathrm{mg} / \mathrm{kg}$ BB per hari (Gürkan and Altunay, 2015).

Secara alami, nitrit bersama dengan nitrat merupakan bagian dari siklus nitrogen. Nitrit dan nitrat dihasilkan dari proses fikssasi nitrogen di alam oleh bakteri Nitrosomonas dan nitrobakter. Nitrit juga dapat terbentuk dari reduksi lebih lanjut nitrat (Koper, 2009). Berbeda dengan nitrit yang bersifat karsinogenik, nitrat dalam tubuh dapat berperan sebagai prokarsinogen. Nitrat dapat bereaksi dengan senyawa kimia lain membentuk senyawa yang bersifat karsinogenik setelah mengalami reduksi terlebih dahulu menjadi nitrit. Paparan nitrit tidak hanya dapat terjadi melalui konsumsi bahan pangan yang mengandung BTP nitrit, karena nitrit juga banyak digunakan dalam produk yang lain seperti pupuk, detergen, bubur kayu, zat pewarna dan industri fiber sintetik. Pemakaian nitrit secara masif pada berbagai bidang industri dapat menyebabkan masalah polusi yang serius. Keberadaan nitrit dalam ekosistem dan lingkungan akuatik dapat mencemari badan air, yang akhinya juga dapat mencemari sumber air minum. Konsumsi bahan pangan yang mengandung nitrat juga berbahaya bagi kesehatan, terutama pada bayi, karena nitrat dapat tereduksi menjadi nitrit dalam perut bayi yang memiliki keasaman yang masih rendah. Oleh karena itu monitoring keberadaan nitrat dan nitrit, terutama di dalam bahan pangan hendaknya menjadi peratian instansi terkait dan dapat dilakukan secara berkala demi menjamin keamanan bahan pangan yang beredar di masyarakat

\section{Simpulan dan saran}

Berdasarkan hasil penelitian tentang analisis kadar nitrit dalam produk daging olahan yang beredar di wilayah Denpasar, dapat diperoleh beberapa simpulan sebagai berikut: 1) Semua sampel uji (18 buah) yang dianalisis mengandung nitrit dengan kadar yang bervariasi yaitu antara 27,392 - 231,362 mg/kg, 2) Kandungan nitrit terendah ditemukan dalam sampel A1 dengan kadar sebesar 27,392 mg/kg dan terbesar dalam sampel F1 dengan kadar sebesar 231,362 mg/kg, dan 3) Terdapat 6 sampel sosis yang mengandung nitrit diatas baku mutu yang telah diatur melalui Permenkes R.I. No. 1168/Menkes/Per/1999 yaitu sampel sampel F1, J1, M1, N1, 01 dan R1.

Berdasarkan hasil penelitian, dapat diberikan beberapa saran sebagai berikut: 1) Instansi terkait diharapkan dapat melakukan sosialisasi mengenai peraturan tentang penggunaan BTP dan bahayanya bagi kesehatan serta edukasi bagi konsumen, terutama tentang bahan pengawet nitrit dalam daging olahan, 2) Instansi terkait diharapkan dapat melakukan monitoring secara berkala terhadap kandungan BTP dalam bahan pangan, terutama nitrit pada produk daging olahan yang telah beredar secara luas di masyarakat, dan 3) Perlu dilakukan analisis kadar nitrit dalam produk daging olahan lain dan produk pangan lain serta analisis kandungan nitrit dalam air minum.

\section{Daftar Rujukan}

Adnan Aydın, Özgen Ercan dan Sülin Taşcioğlu, 2005. A Novel Method for The Spectrophotometric Determination of Nitrite in Water. Talanta, 66, 1181-1186.

Cory, M. S., 2009. Analisis Kandungan Nitrit dan Pewarna Merah pada Daging Burger yang Dijual di Grosir Bahan Baku Burger Di Kota Medan Tahun 2009. Skripsi, Fakultas Kesehatan Masyarakat, Universitas Sumatera Utara, Medan.

Hasna Hayati Nur dan Dyah Suryani, 2012. Analisis Kandungan Nitrit dalam Sosis pada Distributor Sosis di Kota Yogyakarta Tahun 2011. Kes Mas, Vol. 6 No.1 Januari 2012, 1-12.

Husni, E., Samah, A. dan Ariati, R., 2007. Analisa Zat Pengawet dan Protein. Jurnal Sains dan Teknologi Farmasi Universitas Andalas Padang, Vol 12, No.2, 108-111.

Ibnu Gholib Gandjar dan Abdul Rohman, 2007. Kimia Farmasi Analisis. Pustaka Pelajar, Yogyakarta. 
J. Gómez, N. Sanjuán, J. Bon, J. Arnau and G. Clemente, 2015. Effect of Temperature on Nitrite and Water Diffusion in Pork Meat, J. Food Eng., 149, 188-194.

Koper, Marc T. M., Rosca, Victor, Matteo Duca and Matheus T. De Groot, 2009. Nitrogen Cycle Electrocatalysis. Chem. Rev., 109, 2209-2244.

Mardatillah, 2008. Hubungan Kebiasaan Konsumsi Makanan Cepat Saji Modern (Fast Food), Aktivitas Fisik dan Faktor Lainnya dengan Kejadian Gizi Lebih pada Remaja SMA Islam PB. Soedirman Di Jakarta Timur Tahun 2008.

Menteri Kesehatan R.I., 2012. Peraturan Menteri Kesehatan Republik Indonesia. Nomor 033 Tahun 2012 Tentang Bahan Tambahan Pangan available at: http://idih.pom.go.id/produk/peraturanmenteri/Permenkes ttg BTP.pdf (diakses pada 4 Desember 2017).

Moorcroft, Matthew J., James Davis and Richard G. Compton, 2001. Detection and Determination of Nitrate and Nitrite: A Review. Talanta, 54, 785-803.

Muchtadi, 1989. Aspek Biokimia dan Gizi Dalam Keamanan Pangan. Pusat Antar Universitas Pangan dan Gizi Institut Pertanian Bogor.

Nahid Pourreza, Mohammad Reza Fat'hi and Ali Hatami, 2012. Indirect Cloud Point Extraction and Spectrophotometric Determination of Nitrite in Water and Meat Products, Microchem. J., 104, 22-25.

Nidal A. Zatar, Maher A. Abu-Eid and Abdullah F. Eid, 1999. Spectrophotometric Determination of Nitrite and Nitrate Using Posphomolybdenum Blue Complex. Talanta, 50, 819-826.

Noerdiansyah Siregar, 2003. Analisis Kadar Nitrit pada Daging Sosis dengan Metode Spektrofotometri. Skripsi, USU.

Padmarajaiah Nagaraja, Naef Ghllab S. Al-Tayar, Anantharaman Shivakumar, Ashwine K. Shrestha and Avinash K. Gowda, 2010. A Simple and Sensitive Spectrophotometric Method for The Determination of Trace Amounts of Nitrite in Environmental and Biological Samples Using 4-Amino-5Hydroxynaphthalene-2,7-Disulphonic Acid Monosodium Salt. Spectrochim. Acta Part A, 75, 14111416.

Purbanugraha, H.S., 1998. Kadar Nitrit Dendeng Sapi Berlabel dan Non Label di Kodia Yogyakarta. Skripsi, Fakultas Kedokteran, Universitas Gadjah Mada, Yogyakarta.

Ramazan Gürkan and Nail Altunay, 2015. Preconcentration and Indirect Quantification of Trace Nitrite, Nitrate and Total Nitrite in Selected Beverage and Milk Samples Using Ion-Pairing Cloud-Point Extraction with Acridine Orange. J. of Food Comp. and Anal., 1-12.

Saparinto, C., Diana H., 2006. Bahan Tambahan Pangan. Yogyakarta: Kanisius.

Science Lab. Chemical \& Laboratory Equipment: Material Safety Data Sheet Sodium Nitrit MSDS [online], available at: $\underline{w w w . s c i e n c e l a b . c o m / m s d s . p h p ? m s d s I d=992727 . ~(d i a k s e s ~ p a d a ~} 29$ November 2017).

Setiowati, 2015. Analisis Nitrit dan Nitrat di dalam Air Minum dengan Metode Spektrofotometri UV-Vis Menggunakan Asam p-aminobenzoat. Tesis, Universitas Gadjah Mada.

Sun, Jie., Xueji Zhang, Mark Broderick and Harry Fein, 2003. Measurement of Nitric Oxide Production in Biological System by Using Griess Reaction Assay. Sensors., 3, 276-284. 